\title{
Real-Time PCR Assays for Detection and Quantification of Sweetpotato Viruses
}

\author{
C. D. Kokkinos and C. A. Clark, Department of Plant Pathology and Crop Physiology, Louisiana Agricultural Ex- \\ periment Station, Louisiana State University Agricultural Center, Baton Rouge 70803
}

\begin{abstract}
Kokkinos, C. D., and Clark, C. A. 2006. Real-time PCR assays for detection and quantification of sweetpotato viruses. Plant Dis. 90:783-788.

Viral diseases, especially those caused by mixed infections, are among the economically most important diseases of sweetpotato. The difficulties inherent in detecting, quantifying, and isolating viruses directly from sweetpotato have impeded progress in sweetpotato virus research. Real-time polymerase chain reaction (PCR) assays were developed for the detection and relative quantification in singleplex reactions of the potyviruses Sweet potato feathery mottle virus (SPFMV), Sweet potato virus G (SPVG), and Ipomoea vein mosaic virus (IVMV); the crinivirus Sweet potato chlorotic stunt virus (SPCSV); and the begomovirus Sweet potato leaf curl virus (SPLCV) directly from infected sweetpotato plants. There was no significant effect from potential inhibitors in total nucleic acid extracts from sweetpotato leaves on the performance of the real-time PCR assays. Virus titers of SPFMV, IVMV, and SPVG were quantified using real-time PCR and found to be lower in singly infected sweetpotato plants compared with singly infected Brazilian morning-glory (Ipomoea setosa Ker.) and I. nil cv. Scarlet O'Hara plants. Real-time PCR was a more efficient detection method for SPLCV than conventional PCR assay.
\end{abstract}

Additional keywords: Beauregard, Ipomoea batatas, virus quantification

Sweetpotato (Ipomoea batatas (L.) Lam.) is the third most important root crop in the world, ranking seventh among all crops in global production and fourth in developing countries after rice, wheat, and corn (10). In Africa, sweetpotato plays a vital role in peoples' ability to sustain their families, especially during periods of hardship. However, sweetpotato plants, like other crops, are significantly affected by viral diseases. The cultural practice of vegetative propagation provides an efficient way for viruses to be perpetuated and disseminated between cropping seasons or growing areas (22). Several viral diseases have been reported in sweetpotato, but only a few have been well studied and characterized $(3,22)$. Sweetpotato viruses are difficult to transmit mechanically, they are not transmitted through seed, and their host range often is restricted to the family of Convolvulaceae $(18,26)$.

The lack of progress in sweetpotato virus identification and classification is due to two important factors: the difficulty in isolating and purifying viruses from sweetpotato and the high frequency of

Corresponding author: C. A. Clark

E-mail: cclark@agctr.lsu.edu

Approved for publication by the director of the Louisiana Agricultural Experiment Station as journal series no. 05-38-0271.

Accepted for publication 26 January 2006

DOI: 10.1094/PD-90-0783

(C) 2006 The American Phytopathological Society mixed infections and synergistic complexes (7). The most common sweetpotato virus is Sweet potato feathery mottle virus (SPFMV), a member of the Potyvirus genus and Potyviridae family. It occurs virtually everywhere sweetpotato is grown, including countries in tropical and subtropical areas as well as in temperate regions (22). The universal presence of SPFMV often has masked the presence of other viruses in sweetpotato, especially those belonging to the same family, such as Sweet potato virus G (SPVG) and Ipomoea vein mosaic virus (IVMV), making the effort to detect or isolate them specifically very difficult (24). Sweet potato chlorotic stunt virus (SPCSV), a whiteflytransmitted member of the genus Crinivirus and the family Closteroviridae, interacts synergistically with SPFMV to cause sweet potato virus disease (SPVD), the most serious disease of sweetpotato in Africa, where it was first reported, or in South America, where is has been found more recently $(5,21,25)$. Sweet potato leaf curl virus (SPLCV), a whitefly-transmitted geminivirus, and related begomoviruses, have been reported from a handful of locations around the globe, including Taiwan (2), Japan (20), Israel (6), and the United States (14). However, the geographic range of this virus is largely unknown and it may well be present in regions from which it has not yet been reported (4). Further understanding of the biology of these viruses is the most important prerequisite to their proper and effective control. The objective of this work was to develop real-time polymerase chain reaction (PCR) assays for the detection and quantification of selected sweetpotato viruses directly from sweetpotato plants; quantify and compare titer levels of SPFMV, IVMV, and SPVG in different host plants; and evaluate this method as an alternative detection assay for SPCSV and SPLCV.

\section{MATERIALS AND METHODS}

Plant material for potyvirus quantification. I. setosa seedlings were mechanically inoculated separately with the russet crack strain of SPFMV (SPFMV-RC, isolate 95-2), IVMV (isolate LSU-2), and SPVG (isolate LSU-1) to generate the scions that were used to graft inoculate the virus-tested, clonally propagated $I$. batatas $\mathrm{cv}$. Beauregard and the seed-propagated $I$. setosa Ker. and I. nil 'Scarlet O'Hara' (SOH) test plants. Test plants were graft inoculated 3 weeks after planting. Two wedge grafts were made per plant by inserting a single node from the source plant into a slit in the stock plant, and only those on which scions survived for 3 weeks were used. Each treatment was replicated six times. Plants were grown under standard greenhouse conditions in 15 -cm-diameter clay pots containing autoclaved soil mix consisting of 1 part river silt, 1 part sand, 1 part Jiffy-Mix Plus (Jiffy Products of America Inc., Norwalk, OH) and Osmocote 14-14-14 (Scotts-Sierra Horticultural Products Company, Marysville, $\mathrm{OH}$ ) at 3.5 $\mathrm{g} /$ pot. A weekly insecticide spray program was used to control aphids and whiteflies. At 3 and 6 weeks after inoculation, three consecutive leaves collected from the middle of each test plant were combined and immediately frozen in liquid nitrogen and stored at $-80^{\circ} \mathrm{C}$ until extraction.

Total nucleic acid extractions. Frozen leaf tissue was ground to a fine powder in liquid nitrogen using a mortar and pestle and total RNA and DNA were extracted using Qiagen's RNeasy Plant Mini Kit (Qiagen Inc., Valencia, CA) and GenElute Plant Genomic DNA Miniprep Kit (SigmaAldrich, St. Louis), respectively, according to the manufacturers' directions. To eliminate residual DNA contamination, all total RNA samples were treated on-column with DNase I using the RNase-Free DNase Set (Qiagen Inc.). The DNase treatment was performed as an optional step during the RNA extraction based on the manufacturer's directions.

Primer and minor groove binding probe development. For each of the five viruses (SPFMV, SPVG, IVMV, SPCSV, and SPLCV) a set of primers, including a 
forward and a reverse primer, and a fluorogenic probe (TaqMan FAM/minor groove binding [MGB] probe) were designed using the Primer Express software according to the manufacturer's guidelines for primer/MGB probe design (Applied Biosystems, Foster City, CA). Before a potential primer/probe set was used, its putative amplicon sequence (between 63 and $71 \mathrm{bp}$ long) was compared with available sequences in the GenBank using the BLAST sequence alignment search tool, available online from the National Center for Biotechnology Information (NCBI), as an initial step in eliminating nonspecific primer/probe candidate sets. The second step involved the actual testing of the selected primer/probe sets against templates of either total RNA or DNA extracted from leaves of sweetpotato plants graft inoculated separately with SPFMV-RC, IVMV, SPVG, SPCSV (isolate BWFT-3), and the United States strain of SPLCV, SPLCV-US (isolate SWFT-1). In addition, the SPFMV primer/MGB probe set was tested against preparations of SPFMV-RC and SPFMV-C (common strain of SPFMV) particles purified following the procedures of DiFeo et al. (8) and adjusted to a concentration of $25 \mu \mathrm{g} / \mathrm{ml}$ based on absorption at 260 and $280 \mathrm{~nm}$. Total RNA and DNA extracts from virus-tested plants were included in each test. The third and final step involved the construction of standard curves of at least five points that could be used for quantitative assays. RNA or DNA samples that contained high amounts of a specific target were identified through preliminary real-time PCR assays and serially 10 -fold diluted to generate the actual standard curve samples.

Real-time PCR assays for RNA and DNA viruses. Real-time PCR assays for RNA viruses were performed in $50-\mu \mathrm{l}$ reaction volume mixtures with $5 \mu$ of template RNA, $900 \mathrm{nM}$ each primer, 200 nM MGB TaqMan probe, $25 \mu \mathrm{l}$ of the $2 \times$
Master Mix without UNG (Applied Biosystems), and $1.25 \mu \mathrm{l}$ of the $40 \times$ MultiScribe and RNase inhibitor mix (Applied Biosystems). The $2 \times$ and $40 \times$ mixes above are the components of the TaqMan One Step PCR Master Mix Reagents kit (Applied Biosystems). The same protocol was used for the endogenous control reactions (for normalization between samples in quantitative assays), except for the substitution of the primers and probe designed for the target virus with $2.5 \mu$ of the eukaryotic 18S rRNA predeveloped primer/probe mix (VIC/MGB probe). The following real-time PCR thermal cycler conditions were used: $48^{\circ} \mathrm{C}$ for $30 \mathrm{~min}$ (cDNA synthesis) and $95^{\circ} \mathrm{C}$ for $10 \mathrm{~min}$ (AmpliTaq Gold activation), followed by 40 cycles of denaturation at $95^{\circ} \mathrm{C}$ for $15 \mathrm{~s}$ and annealing/extension at $60^{\circ} \mathrm{C}$ for $1 \mathrm{~min}$.

Real-time PCR assays for the DNA virus SPLCV also were performed in 50- $\mu \mathrm{l}$ reaction volume mixtures with $5 \mu \mathrm{l}$ of template DNA, $900 \mathrm{nM}$ each primer, 200 nM MGB TaqMan probe, and $25 \mu \mathrm{l}$ of the TaqMan Universal Master Mix without UNG (Applied Biosystems). The following real-time PCR thermal cycler conditions were used: $50^{\circ} \mathrm{C}$ for $2 \mathrm{~min}$ and $95^{\circ} \mathrm{C}$ for 10 min, followed by 40 cycles of denaturation at $95^{\circ} \mathrm{C}$ for $15 \mathrm{~s}$ and annealing/extension at $60^{\circ} \mathrm{C}$ for $1 \mathrm{~min}$. The same protocol was used for the amplification of the endogenous control, except for the substitution of the primers and probe designed for the target virus with $2.5 \mu \mathrm{l}$ of the eukaryotic 18S rRNA predeveloped primer/probe mix (VIC/MGB probe; Applied Biosystems).

All real-time PCR reactions were performed on an ABI PRISM 7000 Sequence Detection System using MicroAmp optical 96-well reaction plates that were sealed with optical adhesive covers (Applied Biosystems). The thermal cycling parameters described above were optimized for use with the TaqMan Universal Master Mix and TaqMan One Step PCR Master
Mix Reagents kits in singleplex reactions (Applied Biosystems). To minimize any errors due to pipetting differences, duplicates of each sample were performed on each plate and their threshold cycle $(\mathrm{Ct})$ values were averaged during data analysis. In addition, every plate included nontemplate water controls (NTC) as well as positive (total RNA or DNA from virusinfected tissue) and negative (total RNA or DNA from healthy tissue) controls.

Test for inhibitors in total RNA extracts. A sample of total RNA, extracted from leaf tissue of a virus-tested sweetpotato plant, was serially 10 -fold diluted five times to generate a total of six dilutions. From each of the six dilution samples, $5 \mu \mathrm{l}$ was spiked with a 5- $\mu \mathrm{l}$ aliquot from purified particles of SPFMV-RC and used as template in a real-time PCR assay. The $\mathrm{Ct}$ values were compared among the six samples. In addition, two aliquots from purified SPFMV-RC were 10-fold diluted twice to generate two identical groups of three dilutions. One set was spiked with 5 $\mu \mathrm{l}$ from a total RNA extract from leaves of a virus-tested sweetpotato plant (spiked) and the other had $5 \mu \mathrm{l}$ of molecular-grade water added (nonspiked). Both groups of samples were used as templates in the same real-time PCR assay and their $\mathrm{Ct}$ values were compared.

Comparison of real-time and conventional PCR assays for SPLCV. Virustested roots from the sweetpotato cvs. Beauregard, Bienville, Centennial, Jewel, and Xushu-18, grown by the Louisiana State University AgCenter sweetpotato foundation seed program at the Sweet Potato Research Station at Chase, LA, were core grafted with SPLCV-US (SWFT-1), and planted in field beds to generate the plant material for this experiment. Beds initially were covered with black plastic mulch followed by an agricultural fabric (Agribon+ AG-19; PGI Nonwovens, Dayton, NJ) on hoops to ex-

Table 1. Primer/minor groove binding (MGB) probe sets used for the detection and quantification of Sweet potato feathery mottle virus (SPFMV), Sweet potato chlorotic stunt virus (SPCSV), Sweet potato leaf curl virus (SPLCV), Sweet potato virus G (SPVG), and Ipomoea vein mosaic virus (IVMV)

\begin{tabular}{|c|c|c|c|c|}
\hline Name $^{a}$ & Sequence & Amplicon size (bp) & Gene $^{\text {b }}$ & $R / Q$ dyes $^{c}$ \\
\hline \multirow[t]{3}{*}{ SPFMV (AF439637) } & Forward primer: GCCGATTTTAACACCAGATGGA & 63 & $\mathrm{CP}$ & $\ldots$ \\
\hline & Reverse primer: GGTTGCCCACTGTTATTTCCTT & $\ldots$ & $\ldots$ & $\ldots$ \\
\hline & TaqMan probe: CCATAGTGAAGAAGTTC & & & FAM/NFQ \\
\hline \multirow{3}{*}{ SPCSV (AF260321) } & Forward primer: CGAATCAACGGATCGGAATT & 71 & hHsp70 & $\ldots$ \\
\hline & Reverse primer: CCACCGACTATTACATCACCACTCT & $\ldots$ & $\ldots$ & $\ldots$ \\
\hline & TaqMan probe: ATCCCAACGTGTTTATCTA & & & FAM/NFQ \\
\hline \multirow[t]{3}{*}{ SPLCV (AF288227) } & Forward primer: GGCGCCTAAGTATGGCTGAA & 66 & $\mathrm{AC} 1$ & $\ldots$ \\
\hline & Reverse primer: AACCGTATAAAGTATCTGGGAGTGTGT & $\ldots$ & $\ldots$ & $\ldots$ \\
\hline & TaqMan probe: TGTGGGACCCTTTGC & $\ldots$ & $\ldots$ & FAM/NFQ \\
\hline \multirow[t]{3}{*}{ SPVG (AY178991) } & Forward primer: GAATCAAAGGTGAGGAGCAAGAC & 67 & $\mathrm{CP}$ & $\ldots$ \\
\hline & Reverse primer: GCTATGAGCAAATCGTCACCATT & $\ldots$ & $\ldots$ & \\
\hline & TaqMan probe: AGGTTTGCGTCTACTTC & $\ldots$ & & FAM/NFQ \\
\hline \multirow[t]{3}{*}{ IVMV (AY178992) } & Forward primer: GAGACAGCACTGAAAGCTCTGTACA & 70 & $\mathrm{Nib}$ & $\ldots$ \\
\hline & Reverse primer: CACGAACATACTCGGACAAATCTT & $\ldots$ & $\ldots$ & $\ldots$ \\
\hline & TaqMan probe: TGTGTTGAACCATCAGC & $\ldots$ & $\ldots$ & $\mathrm{FAM} / \mathrm{NFQ}$ \\
\hline
\end{tabular}

a The name indicates the virus that the primer/probe set targets followed, in parenthesis, by the GenBank sequence accession number from which the primer/probe sets were developed.

${ }^{\mathrm{b}}$ Viral gene from which primer/probe set was designed.

${ }^{c}$ Type of $5^{\prime}$ reporter/3' quencher (R/Q) dye set attached to each probe; $N F Q=$ nonfluorescent quencher. 
clude any potential virus vectors. Vine cuttings from these beds were transplanted in an isolated field plot and arranged in a randomized complete block design that included four replications of five plants each. Leaves from each replication were collected 22 and 35 days after planting and total DNA was extracted using the method described above. Aliquots of each DNA preparation were used as templates both in a DNA real-time assay as described above and in a conventional PCR assay developed by Lotrakul and Valverde (13). The two methods were compared for their efficiency to detect SPLCV-US.

\section{RESULTS}

The sequences for the primer/probe sets, the fluorescent dyes chosen for each probe, and the GenBank accession numbers of the original sequences from which these sets were designed are listed in Table 1 . The primer/probe SPFMV set amplifies a 63-bp fragment from the coat protein gene of SPFMV-RC (AF439637) and SPFMV-C (AF439638). The primer/probe SPCSV set generates an amplicon of $71 \mathrm{bp}$ from the heat shock 70 homologue (hHsp70) gene of both West African (AJ278653) and Egyptian (AJ515381) isolates. The primer/ probe SPLCV set amplifies a 66-bp fragment from the AC1 gene of the SPLCV-US isolate (AF288227). The SPVG amplicon (67 bp) is generated from the coat protein gene of both LSU-1 (AY178991) and LSU-3 (AY178990) isolates, whereas the IVMV amplicon (70 bp) is homologous to the nuclear inclusion $\mathrm{b}(\mathrm{NIb})$ gene of isolate LSU-2 (AY178992) and Sweet potato virus $Y$ (SPVY AY459608).

Standard curves. Standard curves of at least five duplicated sample dilutions were generated for all five viral targets as well as for the endogenous 18S rRNA reference control (Fig. 1). The correlation between $\mathrm{Ct}$ values and $\log$ relative amounts was very high, with $R^{2}$ above 0.995 for all standard curves. Validation experiments, done as described in User Bulletin \#2 (Applied Biosystems), revealed that the efficiency of amplification between any of the virus targets and the endogenous $18 \mathrm{~S}$ rRNA control was very similar (the slope of $\log$ relative amount versus $\Delta \mathrm{Ct}$ was $<0.1$ ), thus allowing the use of the $\Delta \Delta \mathrm{Ct}$ quantification method which eliminates the need to repeat standard curves each time an assay is conducted. From standard curves generated using purified preparations of SPFMV-C and SPFMV-RC, it was estimated that the SPFMV primer/probe set can detect the virus at $0.25 \mathrm{pg} / \mu \mathrm{l}$.

Test for inhibitors of real-time PCR assays. The threshold cycles of the six purified SPFMV-RC samples spiked with different dilutions of the total RNA extract from virus-tested sweetpotato leaves remained unchanged, clearly indicating that potential inhibitors either were not present or did not have any effect on the perform- ance of the real-time PCR assay (Table 2). Comparison of threshold cycles between samples of "spiked" and "nonspiked" groups indicates that this is true even when the template used was diluted 10 -fold or 100-fold (Fig. 2).

Specificity of primer/probe sets. The primer/probe sets for SPFMV, SPCSV, and SPLCV were specific for the target viruses for which they were designed. Amplification occurred only with homologous combinations, when samples of total RNA from healthy sweetpotato, I. setosa, and $I$. nil plants or I. setosa plants infected with SPFMV-RC, IVMV, or SPVG were tested. Likewise, when total DNA preparations from SPLCV-US-infected sweetpotato leaf tissue were used as template, only the SPLCV primer/probe set amplified. As expected, the SPFMV primer/probe set amplified with the same efficiency both SPFMV-RC (russet crack) and SPFMV-C (common) strains. The SPLCV primer/ probe set amplified with the same efficiency SPLCV from other locations, including Taiwan, Puerto Rico, and Guyana, and, therefore, potentially could be used to monitor the presence of this virus in plant material coming into the United States. Specificity tests involving the SPVG and IVMV primer/probe sets revealed some cross amplification when SPFMV-RC was used as a template. The SPVG primer/ probe set amplified SPFMV-RC at threshold cycles ranging between 33 and 38 and the IVMV primer/probe amplified SPFMV-RC at 31 to 33 cycles, respectively. However, these represent differences of about $10^{7}$ and $10^{5}$ in estimates of virus concentration compared with estimates for the homologous SPVG and IVMV, respectively.

Quantification of SPFMV, IVMV, and SPVG in different hosts. Quantitative assays revealed that, in most sweetpotato plants, the titers of SPFMV-RC were near

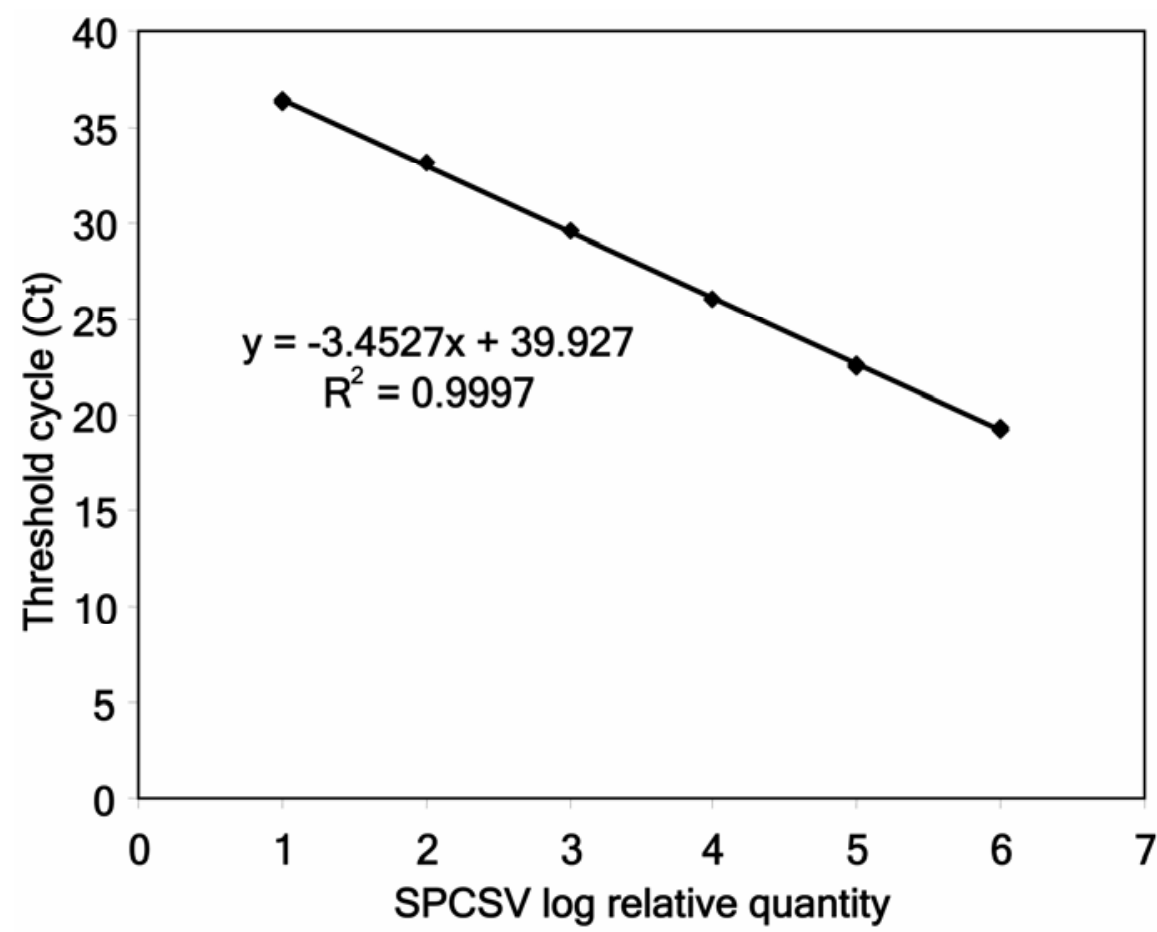

Fig. 1. Standard curve of Sweet potato chlorotic stunt virus (SPCSV), generated by plotting the log of relative quantity of a concentrated source of the virus against critical threshold values from a real-time polymerase chain reaction assay.

Table 2. Real-time polymerase chain reaction $(\mathrm{PCR})$ threshold cycles $(\mathrm{Ct})$ of aliquots of purified preparations of particles of the russet crack strain of Sweet potato feathery mottle virus (SPFMV-RC, isolate 95-2), each spiked with a different concentration of total RNA extract from healthy sweetpotato leaf tissue (RHT)

\begin{tabular}{|c|c|c|}
\hline Template ${ }^{\mathbf{a}}$ & Average $\mathbf{C t}^{\mathbf{b}}$ & Standard deviation $\mathbf{C t}$ \\
\hline SPFMV-RC + RHT (undiluted) & 27.64 & 0.114 \\
\hline SPFMV-RC + RHT ( $10^{1}$-fold dilution $)$ & 27.16 & 0.016 \\
\hline SPFMV-RC + RHT ( $10^{2}$-fold dilution $)$ & 27.78 & 0.156 \\
\hline SPFMV-RC + RHT ( $10^{3}$-fold dilution $)$ & 28.36 & 0.158 \\
\hline SPFMV-RC + RHT ( $10^{4}$-fold dilution) & 27.25 & 0.269 \\
\hline SPFMV-RC + RHT ( $10^{5}$-fold dilution) & 27.38 & 0.041 \\
\hline
\end{tabular}

a Template used in a real-time PCR reaction consisted of $5 \mu \mathrm{l}$ of purified virus and $5 \mu \mathrm{l}$ of total RNA from healthy tissue.

${ }^{\mathrm{b}}$ Mean threshold cycle of duplicate samples. 
the threshold of detection. This was true at both 3 and 6 weeks after inoculation. In $I$. setosa and $I$. nil, the SPFMV-RC titers were greater and the virus was detected in all replicates; however, statistical analysis revealed that, at 3 weeks after inoculation, there was no significant difference $(P=$ 0.0789) in titers among the three hosts.

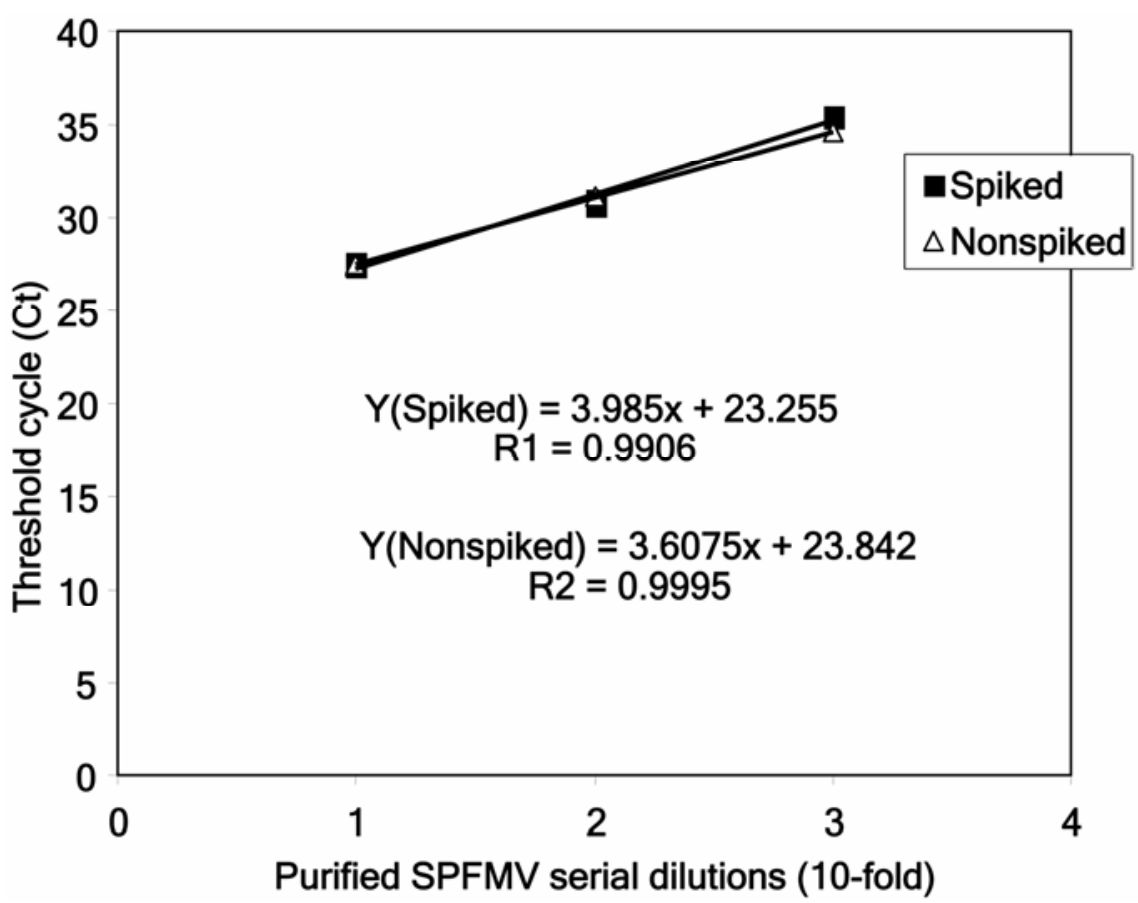

Fig. 2. Comparison of standard curves of purified Sweet potato feathery mottle virus (SPFMV-RC) spiked with $5 \mu \mathrm{l}$ of total RNA extract from healthy sweetpotato tissue (spiked) and purified SPFMV$\mathrm{RC}$ with $5 \mu \mathrm{l}$ of molecular grade water added (nonspiked).

Table 3. Comparison of real-time and conventional polymerase chain reaction (PCR) assays for the detection of the U.S. strain of Sweet potato leaf curl virus (SPLCV-US, isolate SWFT-1) in five sweetpotato cultivars

\begin{tabular}{|c|c|c|c|c|c|}
\hline \multirow[b]{2}{*}{ Cultivar } & \multirow[b]{2}{*}{ Rep } & \multicolumn{2}{|c|}{$\mathbf{P C R}^{\mathrm{a}}$} & \multicolumn{2}{|c|}{ Real-time PCR C $t^{b}$} \\
\hline & & 22 DAP $^{c}$ & 35 DAP & 22 DAP & 35 DAP \\
\hline Beauregard & A & - & + & $18.22+$ & $18.55+$ \\
\hline Beauregard & $\mathrm{B}$ & _- & - & $35.29-$ & $38.75-$ \\
\hline Beauregard & $\mathrm{C}$ & - & - & $20.42+$ & $19.42+$ \\
\hline Beauregard & $\mathrm{D}$ & - & - & $19.66+$ & $19.22+$ \\
\hline Bienville & A & + & + & $17.19+$ & $18.79+$ \\
\hline Bienville & B & + & + & $17.23+$ & $19.10+$ \\
\hline Bienville & $\mathrm{C}$ & _- & + & $18.66+$ & $18.06+$ \\
\hline Bienville & $\mathrm{D}$ & - & + & $17.72+$ & $19.12+$ \\
\hline Centennial & A & _- & + & $18.15+$ & $22.08+$ \\
\hline Centennial & B & + & + & $18.66+$ & $22.04+$ \\
\hline Centennial & $\mathrm{C}$ & + & - & $17.02+$ & $20.03+$ \\
\hline Centennial & $\mathrm{D}$ & - & - & 35.49 - & 37.77 - \\
\hline Jewel & A & - & - & $17.10+$ & $20.97+$ \\
\hline Jewel & $\mathrm{B}$ & + & + & $18.42+$ & $19.99+$ \\
\hline Jewel & $\mathrm{C}$ & - & + & $18.93+$ & $19.16+$ \\
\hline Jewel & $\mathrm{D}$ & _- & - & $18.72+$ & $21.09+$ \\
\hline Xushu & A & - & - & $25.34+$ & $34.64+$ \\
\hline Xushu & B & - & - & $35.02-$ & $32.74+$ \\
\hline Xushu & $\mathrm{C}$ & - & - & $25.19+$ & $30.11+$ \\
\hline Xushu & $\mathrm{D}$ & - & - & $28.95+$ & $27.75+$ \\
\hline $\mathrm{NTC}^{\mathrm{d}}$ & $\ldots$ & - & _- & $>35-$ & $>35-$ \\
\hline Healthy & $\ldots$ & _- & - & $>35-$ & $>35-$ \\
\hline Positive $^{f}$ & $\ldots$ & + & + & $\approx 23+$ & $\approx 23+$ \\
\hline
\end{tabular}

${ }^{\text {a }}$ Detection by agarose gel electrophoresis; + and - indicate presence and absence of the expected size band on the gel.

${ }^{\mathrm{b}}$ Samples with threshold cycles above 35 are considered negative for the presence of this virus.

${ }^{\mathrm{c}} \mathrm{DAP}=$ days after transplanting SPLCV-infected vine cuttings in the field.

${ }^{\mathrm{d}} \mathrm{NTC}=$ no template water control.

${ }^{\mathrm{e}}$ Healthy $=$ a total DNA preparation from a virus-tested sweetpotato plant used as negative control throughout the experiment.

${ }^{\mathrm{f}}$ Positive $=\mathrm{a}$ total DNA preparation from a virus-infected sweetpotato plant used as positive control throughout the experiment.
However, at 6 weeks, titers of SPFMV-RC were higher in I. nil $(P=0.009)$ compared with the other two hosts. In the case of SPVG, titers in all three hosts reached levels that were consistently above the threshold of detection. At 3 and 6 weeks after inoculation, titers were shown to be greater $(P=0.02$ and 0.03 , respectively) in I. setosa and $I$. nil plants compared with sweetpotato plants. IVMV titers reached detectable levels in all three hosts and were greatest in I. nil. However, statistical analysis revealed that titers of IVMV were not different between the three hosts for either assessment date $(P=0.09$ and 0.07 , respectively).

Comparison between real-time and conventional PCR assays for SPLCV. The findings of this experiment for both assessment dates are summarized in Table 3. Overall, the real-time PCR assay detected SPLCV-US in a greater proportion of test plants than the conventional PCR assay. This was especially true during the first assessment date, when the real-time PCR assay detected the virus in 17 of 20 samples tested (total number of samples tested which may include inoculation escapes) compared with 5 of 20 for conventional PCR. For the second assessment date, real-time PCR assay detected the virus in 18 of 20 samples compared with 9 of 20 detected with the conventional PCR assay. By obtaining the relative titer levels of SPLCV-US in samples that were positive by both conventional and real-time PCR, we estimated a 1,000-fold difference between the minimum amounts of virus that each method detected.

\section{DISCUSSION}

Real-time PCR is an extremely useful tool for studying various agents of infectious diseases in human and veterinary pathology (15). In plant pathology, this technology increasingly is used for studying various causal agents of plant diseases $(1,9,19,23)$. This is the first report of the use of real-time PCR technology and TaqMan fluorogenic chemistry for the detection and quantification of sweetpotato viruses. The results obtained in this study show that real-time PCR is not only a faster and safer method (it eliminates more hazardous material, such as ethidium bromide, used in conventional post-PCR analysis) but also, most importantly, a more sensitive method for the detection and quantification of sweetpotato viruses directly from sweetpotato plants compared with existing assays, such as traditional PCR for SPLCV. However, this technology requires the use of special instruments and reagents which are relatively expensive at the present time.

Previous reports suggested that SPFMV is unevenly distributed within a sweetpotato plant $(11,12)$. Real-time PCR data presented here supports this observation and suggests that titers of SPFMV are at 
very low levels, in some cases even below the threshold of detection in plants inoculated with individual potyviruses. The worldwide distribution of this virus, and the fact that yield reductions of singly infected plants are insignificant, $(4,22)$ suggests that today's high-yielding sweetpotato cultivars, which were bred in the presence of this virus, might have been unintentionally selected for resistance to this virus. The ability of this method to provide accurate quantitative data on sweetpotato viruses in different hosts, as illustrated by our experiments, will aid future studies to identify hosts from which vectors may be more likely to acquire viruses.

It has not been clear whether difficulty in detecting SPFMV in sweetpotato by other procedures has been due to inhibitors in sweetpotato that interfere with other types of assays, or low virus titers, or both. Serological reactions may be influenced by inhibitors in sweetpotato such as latex, polyphenols, and polysaccharides, and may explain the difficulty of detecting these viruses in symptomless tissues by enzyme-linked immunosorbent assay (ELISA; 11). This is further supported by McLaughlin et al. (16), who specifically showed that sap from red clover added in the sample buffer significantly decreased the overall sensitivity of their ELISA detection assay of viruses infecting forage legumes. However, no effect was observed when sap from white clover was used, suggesting that inhibitor levels vary greatly even within cultivars of the same species. However, the inherent difficulty in isolating and detecting SPFMV as well as other viruses directly from sweetpotato is reflected in the fact that the majority of studies used indicator plants such as I. setosa, I. nil, and others for the indirect isolation of these viruses $(6,8,14,17,24)$. Even though, at 3 weeks after inoculation, the titers of SPFMV were not different among the three hosts, the titer levels of potyviruses in I. setosa and I. nil were clearly and consistently above the threshold of detection; whereas, in sweetpotato plants, they often were near or below the threshold. The initial virus titers present in each scion at the time of graft inoculation, the rate of graft union formation, and variability in growth rates of each host may account for sample-to-sample variability. However, a high level of variability was not observed at 6 weeks after inoculation. Potyvirus titers were higher in related species than in sweetpotato and there was no evidence of inhibitors of the potyvirus PCR reactions in sweetpotato, suggesting that difficulty in detecting these viruses in sweetpotato is due to low titers rather than inhibitors or problems with the assay. The fact that the titers of all three potyviruses were higher in I. nil also may explain the higher efficiency of aphid transmissions of these viruses from this host compared with sweetpotato (unpublished data).
Even though SPLCV is an important agent of disease (it can reduce yields of Beauregard by $30 \%$ and reduce quality; 4), its importance has been overlooked because symptoms are not commonly found on sweetpotato plants. Symptoms can be mild or transient and may require, in addition to SPLCV, a susceptible cultivar, favorable environment, and co-infection with SPFMV (4). Due to the mild nature of the symptoms caused by SPLCV, even on indicator plants, specific and sensitive methods are a prerequisite for its reliable detection (4,13). Real-time PCR efficiently detected SPLCV in the majority of the total DNA preparations (from SPLCVinoculated sweetpotato) tested. The sensitivity of detection of SPLCV in addition to the quantitative capabilities of this method will aid future studies of the distribution and interactions of this virus with unrelated viruses.

SPVD has not been reported in the United States and SPCSV has been found only in an isolated tissue culture sample (21); therefore, a sensitive detection assay such as the one described here is of major importance in screening germ plasm introduced from countries where this virus is present. The real-time PCR assay reported here provided a highly sensitive assay that allowed unequivocal detection of SPCSV as opposed to the often ambiguous results obtained with conventional PCR and ELISA assays (C. A. Clark, unpublished data).

Viral diseases of sweetpotato, especially those caused by commonly occurring mixed infections, are among the most economically important diseases of this crop. The sensitive quantitative capabilities of the real-time PCR assays provided, for the first time, important information on replication rates of three potyviruses in different hosts. Future experiments will utilize the quantitative capabilities of real-time PCR to study known synergistic interactions as well as identify novel ones through titer quantification.

\section{ACKNOWLEDGMENTS}

Portions of this work were funded by the Louisiana Sweet Potato Advertising and Development Commission and by Specific Cooperative Agreement \#58-6402-4-031 with the United States Department of Agriculture-Agricultural Research Service, Southern Insect Management Research Unit, Stoneville, MS. We thank M. Hoy and L. McKoin for technical assistance, and. R. A. Valverde and K. E. Damman for critically reviewing this manuscript.

\section{LITERATURE CITED}

1. Boonham, N., Smith, P., Walsh, K., Tame, J., Morris, J., Spence, N., Benison, J., and Barker, I. 2002. The detection of Tomato spotted wilt virus (TSWV) in individual thrips vectors using real-time fluorescent RT-PCR (TaqMan). J. Virol. Methods 101:37-48.

2. Chung, M. L., Liao, C. H., Chen, M. J., and Chiu, R. J. 1985. The isolation, transmission and host range of sweetpotato leaf curl disease agent in Taiwan. Plant Prot. Bull (Taiwan) 27:333-342.
3. Clark, C. A., and Moyer, J. W. 1998. Compendium of Sweet Potato Diseases. American Phytopathological Society Press, St. Paul, MN

4. Clark, C. A., Valverde, R. A., Fuentes, S Salazar, L. F., and Moyer, J. W. 2002. Research for improved management of sweetpotato pests and diseases: cultivar decline. Pages 103 112 in: Proc. 1st Int. Symp. Sweetpotato. T. Ames, ed. Acta Hortic. 583.

5. Cohen, J., Frank, A., Vetten, H. J., Leseman, D. E., and Loebenstein, G. 1992. Purification and properties of closterovirus-like particles associated with a whitefly transmitted disease of sweetpotato. Ann. Appl. Biol. 121:257 268.

6. Cohen, J., Milgram, M., Antignus, Y., Pearlsman, M., Lachman, O., and Loebenstein, G 1997. Ipomoea crinkle leaf curl caused by a whitefly-transmitted Gemini-like virus. Ann. Appl. Biol. 131:273-282.

7. Colinet, D., Nguyen, M., Kummert, J., Lepoivre, P., and Xia, F. Z. 1998. Differentiation among potyviruses infecting sweet potato based on genus- and virus-specific reverse transcription polymerase chain reaction. Plant Dis. 82:223-229.

8. Di Feo, L., Nome, S. F., Biderbost, E., Fuentes, S., and Salazar, L. 2000. Etiology of sweet potato chlorotic dwarf disease in Argentina. Plant Dis. 84:35-39.

9. Frederick, R. D., Snyder, K. E., Tooley, P. W., Berthier-Schaad, Y., Peterson, G. L., Bonde, M. R., Schaad, N. W., and Knorr, D. A. 2000 Identification and differentiation of Tilletia indica and $T$. walkeri using the polymerase chain reaction. Phytopathology 90:951-960.

10. Food and Agricultural Organization. 2000. Food and Agricultural Organization statistics. Food and Agricultural Organization of the United Nations, Rome, Italy.

11. Gibb, K. S., and Padovan, A., C. 1993. Detection of sweet potato feathery mottle virus in sweetpotato grown in northern Australia using an efficient and simple assay. Int. J. Pest Manage. 39:223-228.

12. Green, S., K., Kuo, Y. J., and Lee, D., R. 1988 Uneven distribution of two potyviruses (feathery mottle virus and sweet potato latent virus) in sweet potato plants and its implication on virus indexing of meristem derived plants. Trop. Pest Manage. 34:298-302.

13. Lotrakul, P., and Valverde, R. A. 1999. Cloning of a DNA-A-like genomic component of sweet potato leaf curl virus: nucleotide sequence and phylogenetic relationships. Mol. Plant Pathol. Online publication/1999/0422lotrakul.

14. Lotrakul, P., Valverde, R. A., Clark, C. A., Sim, J., and De La Torre, R. 1998. Detection of a gemivirus infecting sweet potato in the United States. Plant Dis. 82:1253-1257.

15. Mackay, I. M., Arden, K. E., and Nitsche, A. 2002. Survey and summary of real-time PCR in virology. Nucleic Acids Res. 30:12921305 .

16. McLaughlin, M. R., Barnett, O. W., Gibson, P. B., and Burrows, P. M. 1984. Enzyme-linked immunosorbent assay of viruses infecting forage legumes. Phytopathology 74:965-969.

17. Moyer, J. W., Abad, J. A., New J., and Bell, J. 2002. Isolation, identification and detection of undescribed RNA sweetpotato viruses. Pages 121-127 in: Proc. 1st Int. Symp. Sweetpotato. T. Ames, ed. Acta Hortic. 583.

18. Moyer, J. W., and Salazar, L. F. 1989. Viruses and viruslike diseases of sweetpotato. Plant Dis. 73:451-455.

19. Mumford, R., Barker, I., Walsh, K., and Boonham, N. 2000. Detection of Potato mop-top virus and Tobacco rattle virus using a multiplex real-time fluorescent reverse-transcription polymerase chain reaction assay. Phytopathology 90:448-453.

20. Onuki, M., and Hanada, K. 1998. PCR amplification and partial nucleotide sequences of three 
Dicot-infecting geminiviruses occurring in Japan. Ann. Phytopathol. Soc. Jpn. 64:116-118.

21. Pio-Ribeiro, G., Winter, S., Jarret, R. L., Demski, J. W., and Hamilton, R. I. 1996. Detection of sweet potato virus disease-associated closterovirus in a sweet potato accession in the United States. Plant Dis. 80:551-554.

22. Salazar, L. E., and Fuentes, S. 2001. Current knowledge on major virus diseases of sweetpotatoes. Pages 14-19 in: Proc. Int. Workshop Sweetpotato Cultivar Decline
Study. Miyakonojo, Japan.

23. Schaad, N. W., Opgenorth, D., and Gaush, P. 2002. Real-time polymerase chain reaction for one-hour on-site diagnosis of Pierce's disease of grape in early season asymptomatic vines. Phytopathology 92:721-728.

24. Souto, E. R., Sim, J., Chen, J., Valverde, R. A., and Clark, C. A. 2003. Properties of strains of Sweet potato feathery mottle virus and two newly recognized potyviruses infecting sweetpotato in the United States. Plant
Dis. 87:1226-1232.

25. Winter, S., Purac, A., Leggett, F., Frison, E. A., Rossel, H. W., and Hamilton, R. L. 1992. Partial characterization and molecular cloning of a closterovirus from sweet potato infected with the sweet potato virus disease complex from Nigeria. Phytopathology 82:869-875.

26. Wolters, P. Collins, W., and Moyer, J. W. 1990 Probable lack of seed transmission of sweet potato feathery mottle virus in sweet potato. HortScience 25:448-449. 